\title{
Review on Application of Augmented Reality (AR) in The Eco-Tourism Sector
}

Mohamad Quzami An-Nuur bin Ahmad Radzi, Dianna Suzieanna Mohamad Shah, Muhammad Fikri Saidi Othman, Muhammad Nor Razin Mhd Nor, Muhammad Farhan Fauzan bin Masaat

To Link this Article: http://dx.doi.org/10.6007/IJARBSS/v11-i11/11377

DOI:10.6007/IJARBSS/v11-i11/11377

Received: 17 September 2021, Revised: 22 October 2021, Accepted: 01 November 2021

Published Online: 26 November 2021

In-Text Citation: (Radzi et al., 2021)

To Cite this Article: Radzi, M. Q. A.-N. bin A., Shah, D. S. M., Othman, M. F. S., Nor, M. N. R. M., \& Masaat, M. F. F. bin. (2021). Review on Application of Augmented Reality (AR) in The Eco-Tourism Sector. International Journal of Academic Research in Business and Social Sciences, 11(11), 2327-2338.

Copyright: (c) 2021 The Author(s)

Published by Human Resource Management Academic Research Society (www.hrmars.com)

This article is published under the Creative Commons Attribution (CC BY 4.0) license. Anyone may reproduce, distribute, translate and create derivative works of this article (for both commercial and non0-commercial purposes), subject to full attribution to the original publication and authors. The full terms of this license may be seen

at: http://creativecommons.org/licences/by/4.0/legalcode

Vol. 11, No. 11, 2021, Pg. 2327 - 2338

Full Terms \& Conditions of access and use can be found at http://hrmars.com/index.php/pages/detail/publication-ethics 


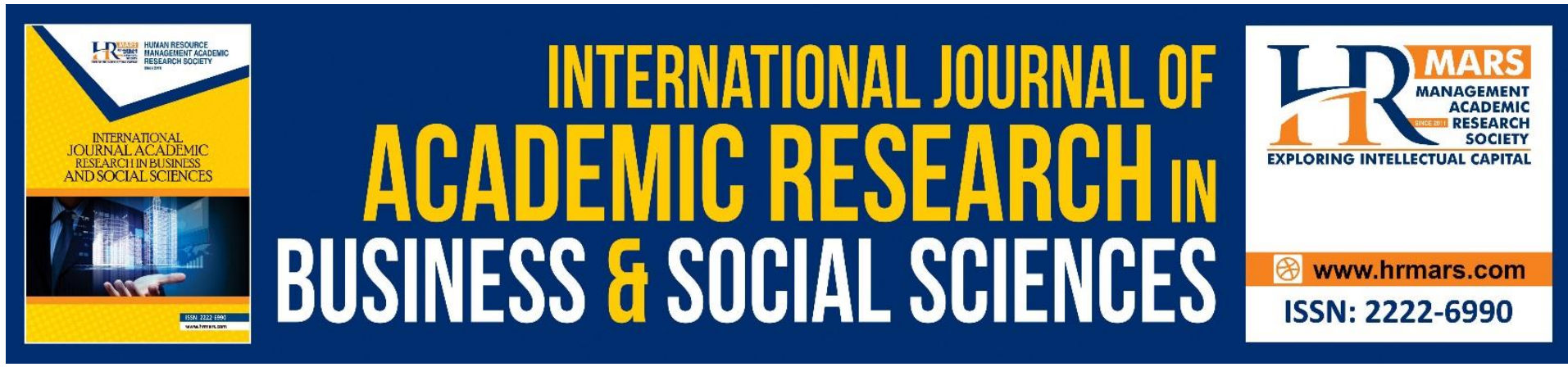

\title{
Review on Application of Augmented Reality (AR) in The Eco-Tourism Sector
}

\author{
Mohamad Quzami An-Nuur bin Ahmad Radzi
}

Faculty of Art and Design, Universiti Teknologi Mara Perak Branch, Malaysia

Dianna Suzieanna Mohamad Shah

Akademi Pengajian Bahasa, Universiti Teknologi Mara Perak Branch, Malaysia

\section{Muhammad Fikri Saidi Othman, Muhammad Nor Razin Mhd Nor}

Faculty of Art and Design, Universiti Teknologi Mara Perak Branch, Malaysia

\section{Muhammad Farhan Fauzan bin Masaat}

Faculty of Science and Information Technology, International Islamic University College, Selangor

\begin{abstract}
There is a tendency at this moment to see augmented reality (AR) application to be used in eco-tourism sector. In this day and age of the Fourth Industrial Revolution, the way we communicate with the aid of technology has already been revolutionized, making things easier and quicker than ever before. The advancements in artificial intelligence (AI) have allowed us to broaden the scope of their functional implementations to include advanced, personalized, and more 'human' areas. This research paper shares findings form a study of augmented reality characteristics in the eco-tourism sector. Quantitative data from existing augmented reality, virtual reality and mixed reality characteristics and previous research in the market provide a significant perspective on the topic of characteristics of AR for ecotourism sector. Four major practices in eco-tourism sector were examined to understand more on AR characteristics: Local community involvement, nature literacy, incomegenerating and natural environment. Findings from this research paper show that much more needs to be achieved not only in the creation and implementation of AR in eco-tourism sector but also, more precisely, in order to ensure that the process of familiarizing and normalizing the use of AR with eco-tourism is more aggressive.
\end{abstract}

Keywords: Eco-tourism, Augmented Reality, Tourism, Tourism Technology, AR

\section{Introduction}

The exponential growth of technology has offered a lot of useful applications to its users. One of the applications created is Augmented Reality. Augmented Reality (AR) promotes 
memorable interactive experience to its customers. It is an immersive perception of a realworld setting in which objects existing in the actual life are augmented by computergenerated perceptual knowledge, often through multiple sensory modalities, including visual, auditory, haptic, somatosensory and olfactory (Azuma, 1997). Previous studies have shown similarities in the definition of $A R$, where $A R$ is described as an evolving type of practice that enhances the real world through computer-generated content that is linked to specific locations or events (Alkhamisi \& Monowar, 2013).

AR was accepted as an evolving technology in 2007, and we are beginning to adopt this very fresh and thrilling kind of human-computer interaction with today's mobile phones and AR browsers (Van Krevelen \& Poelman, 2010). AR is one of the components of mixed reality whereby the surrounding environment is replaced with a synthetic one by both virtual realities (or virtual reality) and augmented virtuality in which actual objects are linked to virtual ones. The first AR system was created in 1968 by Ivan Sutherland. It uses an optical view-through head-mounted monitor that is monitored by one of two separate 6DOF trackers: a mechanical tracker and a tracker (Arth et al., 2015).

\section{Research Objectives}

- To determine augmented reality characteristics

- To analysing strongest augmented reality characteristic for tourism sector

\section{Research Background}

\section{Augmented Reality (AR)}

The demands of AR technology are much higher through times. Following Sutherland's work, Louis Rosenberg developed the first truly interactive AR device in the U.S. Air Force Research Laboratory to substitute for the shortage of high-speed 3D graphics processing power in the early 1990s. It has allowed the overlay of sensory input on a workspace to increase human efficiency (Rosenberg, 1992; Li et al., 2015). This shows that AR seeks to enhance the experience of the user by adding visual knowledge not only to the immediate vicinity, but also to every indirect perception of the real-world environment.

Looking at the idea of AR, AR clearly promotes interactive design. Allanwood and Beare (2015) in page 55 mentioned that interactive design is one of the components in digital media. They also added in their study that there are no clear terms that may describe the definition of interactive design. This is because the increasing advancement of technologies and the digital revolution have altered the understanding and importance of interactive design. However, as put forward by Goodman et al. (2011), interactive design is the specification of digital behaviours in response to human or machine stimuli. Hence, interactive design can be understood as a system of interaction between users and products (machines). AR, as a revolutionary technology tool, is becoming an inseparable part of the marketing of destinations in various countries around the world, which may lead to the successful use of $A R$ in tourism destination marketing. AR is one of the most evolving modes of technology and in the coming years it will be more useful. For those employed in travel-based sectors, this technological breakthrough has been mostly advantageous. Augmented Reality, or AR, provides an impressive sales experience and augmented worlds that can be improved in the tourism industry in different ways. 


\section{The Usage of AR in Industry}

For several decades, AR technology is used in many industries, including education, military, medical, manufacturing, tourism and advertising (Sirakaya \& Sirakaya, 2018; Wu et al., 2013; Yen, Tsai, \& Wu, 2013). A previous study by Hamza-lup (2014) elaborated the idea of incorporating $A R$ in the medical sector. They created a dispersed version of medical instruction intended to train the hand-eye coordination of medical practitioners while conducting endotracheal intubations. The device would allow paramedics, pre-hospital staff and students to exercise their skills without touching a real patient and provide them with the tactile input they may not otherwise receive.

Meanwhile, AR is also applied in a study by Hsieh and Lin (2011) to enhance students' English proficiency. They created a set of Ubiquitous Augmented Reality Digital Learning System (UARDLS) and designed Augmented Reality 3D Digital Media teaching materials based on the content of textbooks. The participants of the study were the elementary school students. They invented an eye-tracking technology to monitor and evaluate their students' eye motions. This is to inspire students' learning motivation. It shows that there is a future for the integration of AR which could play a far larger part in enhancing people's life.

A group of researchers at one of the public universities in Seri Iskandar conducted a research to see whether AR implementation would increase the visibility and experience of students to their learning activities. The project is called ELSA $360^{\circ}$-Videos. ELSA $360^{\circ}$-Videos helps undergraduates from a degree level course on English for Professional and Workplace Simulation to experience what it is like to be in a meeting room. As they share thoughts and deal with difficulties, they can witness and see how peers react to each other and learn valuable communicative skills to succeed in the modern workplace (Adnan et al., 2019).

\section{Augmented Reality in Eco-Tourism}

According to Coria and Calfucura (2012), eco-tourism is characterised as a type of tourism that involves visiting delicate, untouched and natural areas, and that also encourages the preservation of their originality. The tourism sector has undergone different shifts in recent decades. These developments have compelled destinations to advertise their potential effectively in order to be able to gain adequate share from the global world tourism industry, where extreme competition could reach an international level. In order to pursue an effective sales plan and to achieve monophony, cooperative marketing coordination should be made possible for destinations. The key goal is to promote a protected environment for the good of future generations in order to understand and experience its originality. Hence, we believe AR would allow tourists to have new experiences every time they visit a tourist spot. With the enhancement of $A R$, the explanation of each tourist spot, for instance museum or a historic site, could be explained neatly (Othman, 2019). This improved interaction can simplify their quest for travel and for building up their dependency (Asbollah et al., 2017).

Travel experts have also predicted that by embracing the power of AR, various user interfaces can be created which can be useful for the tourism and travel industries (Kourouthanassis et al., 2014). In this case, the presence of augmented reality can offer more interactive and amazing eco-tourism experience among the tourists. However, there is a lack of responsible authorities or agencies that can hold responsibility for it (Mohamed \& Hussin, 2006). Considering the main aspect of the tourist commodity, all organisations operating in the tourism industry must function collectively in order to be effective in the promotion of destinations. Destination marketing agencies require public and private sector partners to help successful branding and positioning. 


\section{Problem of Statement}

AR technology has, until recently, been one of the most outstanding technology. The core premise was the complete inclusion of the user in a computer-generated virtual environment. Thus, AR technologies are therefore becoming increasingly common, not just among the science community, but also among the general public. However, this technology has not been fully utilized by the tourism sector especially in Malaysia. Generally, Malaysia already has vast beautiful lakes, waterfalls, rivers, beaches, national reserve areas and mangroves to be promoted (Anuar et al., 2018). These local eco-tourism sites should be digitally revealed in order to ensure easy access for visitors. Buhalis (2019) proposed that the involvement of technology in the tourism sector might help the sector expand. He added that the tourism sector should now opt for AR to boost its operation. The present AR will also help the ecotourism sector to generate new income by promoting new job vacancy, good income particularly for the local community, in addition to the eco-tourism conservation site (Setini et al., 2021). Therefore, the location of eco-tourism will still become a local natural environment without any damage.

On the other hand, prospective travellers have access to broad knowledge bases that are directly created by the AR system. It will help to reduce the cost to the travel agent as well as to travellers themselves. As Hall and Williams (2019) rightly point out, creativity in tourism can minimize travel costs. The involvement of high technology in tourism will reduce any unseasonable costs for travel agencies and visitors.

\section{Methodology}

This research paper employs quantitative data collected from three phases as stated below.

Table 1: Research Stages

\begin{tabular}{ll}
\hline Stage & Process \\
\hline Stage 1 & $\begin{array}{l}\text { Collect primary data on augmented reality (AR) and the } \\
\text { eco-tourism industry }\end{array}$ \\
Stage 2 & $\begin{array}{l}\text { Identify existing augmented reality application } \\
\text { Stage } 3\end{array}$ \\
\hline
\end{tabular}

\section{Research Phases}

Phase 1: Data collection

Through a process of qualitative research meta synthesis, writings and studies from existing literature, for examples, scientific journals, books, academic dissertations and electronic bibliographic databases, were collected, checked, analysed, and reviewed. A discussion on the parallels and disparities of these studies is included. This is to ensure that more data can be collected and studied to see whether the employed criteria are convenient to construct greater meaning to apply AR in the eco-tourism sector. Other than that, current nature-based eco-tourism activities such as local community engagement, nature-based learning, incomegenerating, and the natural environment have also been studied (Ross \& Wall, 1999).

\section{Phase 2: Collecting existing augmented reality}

In this phase, the examples of existing augmented reality in the market from variety sectors were collected. At the same time, a variety of augmented reality provider applications were also extracted in this phase. 


\section{Phase 3: Data analysis}

Characteristics of augmented reality application were identified. Researchers extracted the characteristics of augmented reality from existing writings and applications. In this phase, researchers identified the suitable characteristics of augmented reality that can be applied for eco-tourism-based applications. This eco-tourism-based application would also apply and be linked to the promotional practice of eco-tourism.

\section{Findings}

\section{Augmented Reality Characteristics}

Researchers identified augmented reality characteristics based on the qualitative meta synthesis where existing writings, publications, and augmented reality applications were collected, checked, analysed, and reviewed. These characteristics gained from the reading were related to the users' experiences and interactive design technology. Below is the list of AR characteristics that had been extracted.

\begin{tabular}{|c|c|c|}
\hline Authors(s) & Title & Characters \\
\hline $\begin{array}{l}\text { Han \& Jung } \\
(2018)\end{array}$ & $\begin{array}{l}\text { Identifying tourist requirements for } \\
\text { mobile AR tourism applications in } \\
\text { urban heritage tourism }\end{array}$ & Meaningful design \\
\hline $\begin{array}{l}\text { Allanwood \& } \\
\text { Beare (2015) }\end{array}$ & $\begin{array}{l}\text { User experience design: Creating } \\
\text { designs that users really love }\end{array}$ & $\begin{array}{l}\text { Fun, usability, simplicity, challenge, gestalt } \\
\text { theory, semiotics, narrative and } \\
\text { constraints }\end{array}$ \\
\hline Steane (2014) & The principles and processes of & Colour, images, typography, layout, grids \\
\hline $\begin{array}{l}\text { Li, Wang, Jiao, } \\
\text { Wang \& Li } \\
\text { (2019) }\end{array}$ & $\begin{array}{l}\text { Research on the visual elements of } \\
\text { augmented reality assembly } \\
\text { processes }\end{array}$ & $\begin{array}{l}\text { Picture, static model, simulation } \\
\text { animation, video, symbol and text }\end{array}$ \\
\hline $\begin{array}{l}\text { Syberfeldt, } \\
\text { Holm, } \\
\text { Danielsson, } \\
\text { Wang, \& } \\
\text { Lindgren } \\
\text { Brewster } \\
\text { (2016). }\end{array}$ & $\begin{array}{l}\text { Support Systems on the Industrial } \\
\text { Shop-floors of the Future - } \\
\text { Operators' Perspective on } \\
\text { Augmented Reality }\end{array}$ & Navigation and wayfinding system \\
\hline $\begin{array}{l}\text { Mohr, Kerbl, } \\
\text { Donoser, } \\
\text { Schmalstieg \& } \\
\text { Kalkofen (2015) }\end{array}$ & $\begin{array}{l}\text { Retargeting Technical } \\
\text { Documentation to Augmented } \\
\text { Reality }\end{array}$ & $\begin{array}{l}\text { Text annotations, arrows with motion \& } \\
\text { graphic interface }\end{array}$ \\
\hline
\end{tabular}




\begin{tabular}{|c|c|c|}
\hline $\begin{array}{l}\text { Julier, } \\
\text { Lanzagorta, } \\
\text { Baillot, } \\
\text { Rosenblum, } \\
\text { Feiner, Hollerer } \\
\text { \& Sestito } \\
\text { (2000) } \\
\text { Keil, Schmitt, } \\
\text { Engelke, Graf \& } \\
\text { Olbrich (2018) }\end{array}$ & $\begin{array}{l}\text { Augmented Reality Views: Discussing } \\
\text { the Utility of Visual Elements by } \\
\text { Mediation Means in Industrial AR } \\
\text { from a Design Perspective }\end{array}$ & Visual elements, annotation \& labels \\
\hline $\begin{array}{l}\text { Gattullo, } \\
\text { Scurati, G } \\
\text { Fiorentino, Uva, } \\
\text { Ferrise \& } \\
\text { Bordegoni } \\
\text { (2019) } \\
\text { Keil, Engelke, } \\
\text { Schmitt, } \\
\text { Bockholt \& } \\
\text { Pujol (2014) }\end{array}$ & $\begin{array}{l}\text { Lean in or Lean Back? Aspects on } \\
\text { Interactivity \& Mediation } \\
\text { in handheld Augmented Reality in } \\
\text { the Museum }\end{array}$ & $\begin{array}{l}\text { Simplified English text using 2D graphic } \\
\text { symbols }\end{array}$ \\
\hline $\begin{array}{l}\text { Wither, } \\
\text { DiVerdi, \& } \\
\text { Höllerer (2009) } \\
\text { Schmalstieg \& } \\
\text { Höllerer (2017) }\end{array}$ & $\begin{array}{l}\text { Annotation in outdoor augmented } \\
\text { reality } \\
\text { Augmented Reality: Principles and } \\
\text { Practice }\end{array}$ & $\begin{array}{l}\text { Taxonomy of annotation } \\
\text { Digital visual vision interactive, } \\
\text { annotation, well modelling \& navigation }\end{array}$ \\
\hline $\begin{array}{l}\text { Kinateder, } \\
\text { Gualtieri, Dunn, } \\
\text { Jarosz,Yangm \& } \\
\text { Cooperm } \\
(2018)\end{array}$ & $\begin{array}{l}\text { Using an augmented reality device as } \\
\text { a distance-based vision aid promise } \\
\text { and limitations. }\end{array}$ & Contrast vision \\
\hline
\end{tabular}

Table 2: Characteristics of Augmented Reality

Based on existing writings, there are several categories of augmented reality characteristics that had been identified. Researchers had adopted key topics from textual analysis by Loureiro et al. (2020) and categorised them. The first category is element and principle of design. This idea is considered as the basic element or theory in art and design. It is one of the new modern arts nowadays (Xi-man, 2016). The second category is annotation which refers to virtual information or object (Wither et al., 2009). Researchers believed that these characteristics are the wayfinding instrument to augmented reality application. The third 
category is user experience. User experience has always become the variable indicator in an interactive multimedia simulation (Allanwood \& Beare, 2015). It also important to improvise how user or audience can feel or experience on the augmented reality application. Animation or video is the fourth category identified for augmented reality characteristic. This may refer to any form of interactive animation with audio narration. The fifth category is symbol. Two dimension and three-dimension symbols can be referred to in this category. Graphic system including visual or any images is the last category that had been identified by the researchers. In this study, graphic system can be referred as the graphic design including visual or images, shape and computer technical design-based software for example, Adobe Illustrator, Adobe Animate and Autodesk Maya. These softwares are the most intuitive way to create, view, and share immersive AR experiences. Table 3 below shows a list of existing papers according to their AR categories.

\begin{tabular}{|c|c|c|c|c|c|c|}
\hline 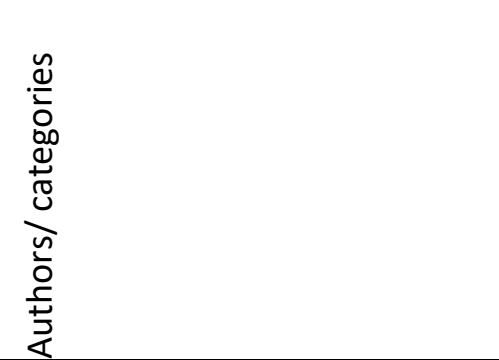 & 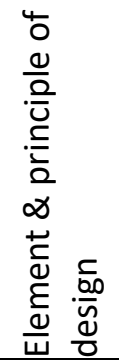 & $\begin{array}{l}\stackrel{0}{0} \\
\stackrel{0}{+} \\
\stackrel{0}{0} \\
\stackrel{0}{c} \\
\frac{c}{4}\end{array}$ & 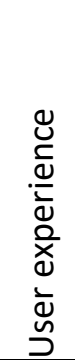 & 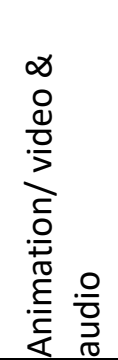 & $\begin{array}{l}\bar{o} \\
\text { है } \\
\text { ఓે }\end{array}$ & 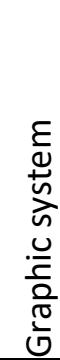 \\
\hline Han \& Jung (2018) & & & / & & & \\
\hline Allanwood \& Beare (2015) & & I & & & I & I \\
\hline Steane (2014) & 1 & & & & & 1 \\
\hline $\begin{array}{l}\text { Li, Wang, Jiao, Wang \& Li } \\
\text { (2019) }\end{array}$ & & & / & / & / & / \\
\hline $\begin{array}{l}\text { Syberfeldt, Holm, Danielsson, } \\
\text { Wang \& Lindgren Brewster } \\
\text { (2016). }\end{array}$ & & / & & & & \\
\hline $\begin{array}{l}\text { Mohr, Kerbl, Donoser, } \\
\text { Schmalstieg \& Kalkofen (2015) }\end{array}$ & & / & / & & & \\
\hline $\begin{array}{l}\text { Julier, Lanzagorta, Baillot, } \\
\text { Rosenblum, Feiner, Hollerer \& } \\
\text { Sestito (2000) }\end{array}$ & & / & & & & / \\
\hline $\begin{array}{l}\text { Keil, Schmitt, Engelke, Graf \& } \\
\text { Olbrich (2018) }\end{array}$ & & / & & & / & / \\
\hline $\begin{array}{l}\text { Gattullo, Scurati, G Fiorentino, } \\
\text { Uva, Ferrise \& Bordegoni } \\
\text { (2019) }\end{array}$ & & / & & & / & \\
\hline $\begin{array}{l}\text { Keil, Engelke, Schmitt, } \\
\text { Bockholt \& Pujol (2014) }\end{array}$ & & & & & / & \\
\hline $\begin{array}{l}\text { Wither, DiVerdi \& Höllerer } \\
\text { (2009) }\end{array}$ & & / & & & & \\
\hline Schmalstieg \& Höllerer (2017) & & I & I & & I & I \\
\hline $\begin{array}{l}\text { Kinateder, Gualtieri, Dunn, } \\
\text { Jarosz,Yangm \& } \\
\text { Cooperm(2018) }\end{array}$ & & & & & & / \\
\hline
\end{tabular}

Table 3: Augmented reality categories 
Based on the above table, annotation is the strongest augmented reality characteristic followed by symbol and graphic system. User experience, element and principle of design with animation or video and audio are other three categories, which have been less discussed by existing scholars. However, researchers identified that the three highest scales in Table 3 are slightly related to other three lowest scale characters.

The typical usage of augmented reality also may affect the most chosen characteristic of augmented reality especially in the eco-tourism sector. The augmented reality characteristics also may differ from the characteristics of virtual and mixed reality. This may happen because of the type of devices, technology and basic user requirements.

\section{Eco-Tourism Sector}

Strategies need to be built to generate a wide variety of new opportunities for the increasing eco-tourism market. In order to expand the possibilities, major eco-tourism practices should be redesigned with the features of augmented reality, utilizing four key ecotourism activities: local community involvement, strong participation, learning-oriented, environmentally sustainable and able to generate revenue. (Ross \& Wall, 1999).

Without a tinge of doubt, strong participation practices, including the tourism prospect, the travel agent and everyone involved in the process of developing this proposal, play a key role in improving the eco-tourism market. As mentioned previously, all organisations operating in the tourism industry must function collectively in order to be effective in the promotion of destinations. Additionally, other ideas in this regard is to use animation or video recording from the actual venue. This will allow visitors to imagine the local community and the natural environment. This is parallel to Anuwar et al (2020), where they claimed that special locations at any eco-tourism location can be promoted using new and creative technology. It can also establish a good combination of animation and video recording at the attraction area of the eco-tourism spot.

Subsequently, tourists using this AR eco-tourism application can also access information by looking at the symbol in the video, which can be referred to as learning oriented. The inclusion of the symbol would also reduce the use of rich text and create more room for eco-tourism images. The video used would project the real world through computer-generated content linked to specific locations or occurence (Alkhamisi \& Monowar, 2013). The stakeholders involve can ensure that this AR technology can include a reality tour of the tour site while at the same time carrying out environmentally friendly activities. It can help tourists have a more real-life experience.

Thus, the three elements in eco-tourism activities namely local community involvement, strong participation, learning-oriented and environmentally sustainable can be combined to produce revenue that can be used to help the eco-tourism industry.

\section{Conclusion}

AR provides different added value multimedia content. Thus, users can experience real life experience. The use of AR in the eco-tourism industry may help this sector become more visible among tourists. By tapping on the screen, you may see a pop-up menu that allows you to select from various fields of interest, showing the precise augmented reality. The use of this technology will also benefit media content activists to produce more digital elements with a relation to eco-tourism more widely through any global platforms.

Augmented Reality is supposed to modify what we see around. It is intended to enrich our enjoyment when travelling the world and maximise our joy. Therefore, AR is the ideal tourism 
instrument. This brings new values and opens new avenues for the tourism and retail sectors alike. The variety of activities from the attractions of an eco-tourism area will also be more vigorous such as kayaking, hiking and fishing. The location of a hot spot on selected ecotourism sites such as beautiful lakes, waterfalls, river, beach, national reserve area and mangroves can be more visible using this AR technology. In the next future, the use of this AR technology will also be the main platform in the variety of packages offered in order to provide improvements to the user experience itself. Hence, content activist or developer from any AR platform provider can also add significant four key elements of eco-tourism practice addressed in this study in their AR application. We therefore assumed that the discussion offered would benefit the local tourism authorities, the tourist office and the traveller.

\section{References}

Adnan, A. H. M., Ahmad, M. K., Yusof, A. A., Kamal, M. A., Kamal, M. N. N. (2019). English language simulations augmented with 360-degree spherical videos (ELSA $360^{\circ}$ Videos): 'Virtual reality' real life learning!. In MNNF Publisher (Ed.), Leading towards creativity \& innovation series 2, 329-343. MNNF Publisher

Alkhamisi, A. O., \& Monowar, M. M. (2013). Rise of augmented reality: current and future application areas. International Journal of Internet and Distributed Systems, 1(4), 2534. https://doi.org/10.4236/ijids.2013.14005.

Allanwood, G., \& Beare, P. (2015). User experience design: Creating designs users really love. Bloomsbury.

Anuar, A. N. A., Jaini, N., Robat, M., \& Jamaluddin, E. R. (2018). The identification of criteria for ecotourism practice in Peninsular Malaysia. Journal of Hotel and Business Management, 8(190), 2169-2186. https://doi: 35248/2169-0286.19.8.190.

Anuwar, N. A. A., Sobri, S. A., Hermawan, A., Hambali, K. A., Ismail, W. O. A. S. W., \& Amini, M. H. M. (2020). The potential of eco-tourism: A narrative case study of Perlis State Park, Malaysia. Journal of Critical Reviews, 7(15), 3070-3077. http://doi: 10.31838/jcr.07.15.422.

Arth, C., Grasset, R., Gruber, L., Langlotz, T., Mulloni, A., \& Wagner, D. (2015). The history of mobile augmented reality. ArXiv Preprint ArXiv:1505.01319. http://arxiv.org/abs/1505.01319.

Asbollah, A. Z., Hassan, N., Yusoff, M. S., \& Idris, H. (2017). The tourist behaviour in different environments: A literature review. Journal of the Malaysia Institute of Planners, 15(1), 279-288. https://doi.org/10.21837/pmjournal.v15.i6.244

Azuma, R. T. (1997). A survey of augmented reality. Presence: Teleoperators \& Virtual Environments, 6(4), 355-385. https://doi.org/10.1162/pres.1997.6.4.355.

Buhalis, D. (2019). Technology in tourism-from information communication technologies to E-Tourism and smart tourism towards ambient intelligence tourism. Tourism Review, 75(1), 267-272. https://doi.org/10.1108/TR-06-2019-0258.

Coria, J., \& Calfucura, E. (2012). Ecotourism and the development of indigenous communities: The good, the bad, and the ugly. Ecological Economics, 73, 47-55. https://doi.org/10.1016/j.ecolecon.2011.10.024.

Gattullo, M., Scurati, G. W., Fiorentino, M., Uva, A. E., Ferrise, F., \& Bordegoni, M. (2019). Towards augmented reality manuals for industry 4.0: A methodology. Robotics and Computer-Integrated Manufacturing, 56, 276-286.

https://doi.org/10.1016/j.rcim.2018.10.001. 
Goodman, E., Stolterman, E., \& Wakkary, R. (2011). Understanding interaction design practices: Paper presentation. Conference on Human Factors in Computing Systems Proceedings, 1061-1070, Vancouver, CA. https://doi.org/10.1145/1978942.1979100.

Hall, C. M., \& Williams, A. M. (2019). Tourism and innovation. London, UK: Routledge.

Hamza-lup, F. G. (2014). A distributed augmented reality system for medical training and simulation. Energy, Simulation-Training, Ocean Engineering and Instrumentation: Research Papers of the Link Foundation Fellows, 1-18 https://arxiv.org/ftp/arxiv/papers/1811/1811.12815.pdf.

Han, D. I., \& Jung, T. (2018). Identifying tourist requirements for mobile AR tourism applications in urban heritage tourism. In T, Jung, M.C. tom Diek (Eds.), Augmented Reality and Virtual Reality, 3-20. https://doi.org/10.1007/978-3-319-64027-3_1.

Hsieh, M. C., \& Koong Lin, H. C. (2011). A conceptual study for augmented reality e-learning system based on usability evaluation. Communications in Information Science and Management Engineering, 1(8), 5-7. https://doi.org/10.5963/cisme0108002.

Julier, S., Lanzagorta, M., Baillot, Y., Rosenblum, L., Feiner, S., Hollerer, T., \& Sestito, S. (2000). Information filtering for mobile augmented reality. In Proceedings IEEE and ACM International Symposium on Augmented Reality (ISAR 2000), (3-11).

Keil, J., Engelke, T., Schmitt, M., Bockholt, U., \& Pujol, L. (2014). Lean in or lean back? Aspects on interactivity \& mediation in handheld augmented reality in the museum: Workshop presentation. Eurographics Workshop on Graphics and Cultural Heritage, 17-20. http://dx.doi.org/10.2312/gch.20141319.

Keil, J., Schmitt, F., Engelke, T., Graf, H., \& Olbrich, M. (2018, July). Augmented reality views: Discussing the utility of visual elements by mediation means in industrial AR from a design perspective. Presented in International Conference on Virtual, Augmented and Mixed Reality, 298-312, Springer, Cham.

Kinateder, M., Gualtieri, J., Dunn, M. J., Jarosz, W., Yang, X. D., \& Cooper, E. A. (2018). Using an augmented reality device as a distance-based vision aid-promise and limitations. Optometry and Vision Science, 95(9), 727-737. https://doi: 10.1097/OPX.0000000000001232.

Kourouthanassic, P.E., Boletsis, C., Bardaki, C., \& Chasanidou, D. (2014). Tourists responses to mobile augmented reality travel guides: The role of emotions on adoption behaviour. Pervasive and Mobile Computing, 18, 71-87. https://doi.org/10.1016/j.pmcj.2014.08.009.

Li, K. C., Tsai, C. W., Chen, C. T., Cheng, S. Y., \& Heh, J. S. (2015). The design of immersive English learning environment using augmented reality. Presented in 8th International Conference on Ubi-Media Computing (UMEDIA), 174-179.

Li, W., Wang, J., Jiao, S., Wang, M., \& Li, S. (2019). Research on the visual elements of augmented reality assembly processes. Virtual Reality \& Intelligent Hardware, 1(6), 622-634. https://doi.org/10.1016/j.vrih.2019.09.006.

Loureiro, S. M. C., Guerreiro, J., \& Ali, F. (2020). 20 years of research on virtual reality and augmented reality in tourism context: A text-mining approach. Tourism Management, 77, 1-21. https://doi.org/10.1016/j.tourman.2019.104028.

Mohamed, B., \& Hussin, A. A. (2006). Ecotourism planning: Who is really responsible? Planning Malaysia Journal of the Malaysian Institute of Planners, 7(4), 557-564. http://dx.doi.org/10.21837/pm.v1i1.33. 
Mohr, P., Kerbl, B., Donoser, M., Schmalstieg, D., \& Kalkofen, D. (2015). Retargeting technical documentation to augmented reality. In Proceedings of the 33rd Annual ACM Conference on Human Factors in Computing Systems, 3337-3346)

Othman, Z. (2019). Postcard from Zaharah: Promoting Malaysian eco-tourism. New Straits Times. https://www.nst.com.my/lifestyle/sunday-vibes/2019/11/539497/postcardzaharah-promoting-malaysian-eco-tourism/

Rosenberg, L. (1992). The Use of Virtual Fixtures as Perceptual Overlays to Enhance Operator Performance in Remote Environments (unpublished thesis). Semantic Scholar.

Ross, S., \& Wall, G. (1999). Ecotourism: towards congruence between theory and practice. Tourism management, 20(1), 123-132. https://doi.org/10.1016/S02615177(98)00098-3.

Schmalstieg, D., \& Höllerer, T. (2017, March). Augmented reality: Principles and practice. In 2017 IEEE Virtual Reality (VR), 425-426.

Setini, M., Wardana, I., Sukaatmadja, I., Ekawati, N., Yasa, N., \& Astawa, I. (2021). Policy models for improving ecotourism performance to build quality tourism experience and sustainable tourism. Management Science Letters, 11(2), 595-608. http://growingscience.com/beta/msl/4310-policy-models-for-improving-ecotourismperformance-to-build-quality-tourism-experience-and-sustainable-tourism.html.

Sirakaya, M., \& Sirakaya, A. D. (2018). Trends in educational augmented reality studies: A systematic review. Malaysian Online Journal of Educational Technology, 6(2), 60-74. https://doi.org/10.17220/mojet.2018.02.005.

Syberfeldt, A., Holm, M., Danielsson, O., Wang, L., \& Brewster, L. R. (2016). Support systems on the industrial shop-floors of the future: Operators' perspective on augmented reality. In 6th CIRP Conference on Assembly Technologies and Systems (CATS), 44, 108113.

Tom, D, M. C., \& Jung, T. (2018). A theoretical model of mobile augmented reality acceptance in urban heritage tourism. Current Issues in Tourism, 21(2), 154-174. https://doi.org/10.1080/13683500.2015.1070801.

Van Krevelen, D. W. F., \& Poelman, R. (2010). A survey of augmented reality technologies, applications and limitations. International Journal of Virtual Reality, 9(2), 1-20. https://doi.org/10.20870/ijvr.2010.9.2.2767.

Wither, J., DiVerdi, S., \& Höllerer, T. (2009). Annotation in outdoor augmented reality. Computers \& Graphics, 33(6), 679-689. https://doi.org/10.1016/j.cag.2009.06.001.

Wu, H. K., Lee, S. W. Y., Chang, H. Y., \& Liang, J. C. (2013). Current status, opportunities and challenges of augmented reality in education. Computers \& education, 62, 41-49. https://doi.org/10.1016/j.compedu.2012.10.024.

Xi-man, S. H. I. (2016). Role of composition principle in modern art design. Art and Design, (3), 12. http://en.cnki.com.cn/Article_en/CJFDTotal-YSLL201603012.htm.

Yen, J. C., Tsai, C. H., \& Wu, M. (2013). Augmented reality in the higher education: Students' science concept learning and academic achievement in astronomy. Procedia-social and behavioural sciences, 103(26), 165-173. https://doi.org/10.1016/j.sbspro.2013.10.322.

Yung, R., \& Khoo-Lattimore, C. (2019). New realities: a systematic literature review on virtual reality and augmented reality in tourism research. Current Issues in Tourism, 22(17), 2056-2081. https://doi.org/10.1080/13683500.2017.1417359. 